Sains Malaysiana 49(1)(2020): 179-188

http://dx.doi.org/10.17576/jsm-2020-4901-22

\title{
Kebolehbentukan-tikso Aloi 2014 dengan Penambahan Si dan Pengurangan $\mathrm{Cu}$
}

(Thixoformability of 2014 Alloy with the Addition of Si and Decreasing of Cu)

\author{
M.A.M. ARIF*, M.Z. OMAR \& Z. SAJURI
}

\section{ABSTRAK}

Dalam kajian ini, kebolehbentukan-tikso aloi aluminium (Al) 2014 dengan penambahan unsur silikon (Si) dan pengurangan unsur kuprum (Cu) dikaji. Kandungan Si dan Cu dalam aloi 2014 diubah suai supaya kriteria kebolehbentukan-tikso dapat dipenuhi. Kebolehbentukan-tikso aloi 2014 dan aloi Al-terubah suai diukur secara termodinamik dengan menggunakan pakej perisian JMatPro dan seterusnya dibuktikan secara uji kaji melalui analisis terma dan analisis fasa. Hasil kajian ini mendapati bahawa sifat kebolehbentukan-tikso aloi 2014 dapat dipenuhi dengan penambahan Si dan pengurangan Cu. Apabila kandungan Si dalam aloi 2014 bertambah, kandungan fasa eutektik pada titik 'lutut' tertinggi yang terbentuk di atas lengkung pecahan cecair meningkat dengan ketara, manakala julat suhu pemejalan pula semakin mengecil. Di samping itu, pengurangan Cu pula menyebabkan julat suhu pemprosesan untuk pembentukan-tikso menjadi semakin luas lalu mengakibatkan sensitiviti pecahan cecair pada titik 'lutut'tertinggi menurun. Selain pembentukan fasa $\mathrm{Al}_{2} \mathrm{Cu}$ dan fasa $\theta-\mathrm{Al}_{5} \mathrm{Cu}_{2} \mathrm{Mg}_{8} \mathrm{Si} i_{6}$, kemunculan fasa $\pi-\mathrm{Al}_{8} \mathrm{FeMg} \mathrm{Si}_{6}$ dengan struktur yang padat hasil daripada pengurangan $\mathrm{Cu}$ juga dijangka menyumbang kepada peningkatan sifat mekanik aloi Alterubah suai. Akhir sekali, aloi Al-terubah suai tersebut dijangka mampu digunakan untuk menghasilkan komponen otomotif seperti rod penyambung, aci sesondol dan aci engkol melalui proses pembentukan-tikso.

Kata kunci: Aloi aluminium; JMatPro; kebolehbentukan-tikso

\section{ABSTRACT}

In the present study, the thixoformability of aluminium (Al) alloy 2014 with the addition of silicon (Si) and the reduction of copper (Cu) was studied. The contents of Si and $\mathrm{Cu}$ in 2014 alloy were modified in order to fulfil the thixoformability criteria. The thixoformability of 2014 alloy and Al-modified alloy were measured thermodynamically using JMatPro software package and validated experimentally via thermal and phase analysis. The study found that the thixoformability behaviour of alloy 2014 had improved with the addition of Si and Cu reduction. When Si content in the alloy was increased, the amount of eutectic phase at the highest 'knee' on the liquid fraction curve increased significantly, while the solidification temperature range decreased. In addition, the reduction in Cu had increased the temperature range for thixoforming process and lowering the liquid fraction sensitivity at the highest 'knee'. In addition to the existence of Al2 $\mathrm{Cu}$ and $\theta-A l 5 C u 2 M g 8$ Si6 phases, the emergence of $\pi$-Al8FeMg3Si6 phase with compact structure resulting from Cu reduction is expected could be contribute to the improvement of the Al-modified alloy mechanical properties. Finally, the modified Al alloy is expected to be suitable to produce automotive components such as connecting rod, camshaft and crankshaft by using thixoforming process.

Keywords: Aluminium alloy; JMatPro; thixoformability

\section{Pengenalan}

Proses pembentukan-tikso merupakan satu daripada proses pembentukan aloi logam yang menghasilkan komponen dengan bentuk hampir siap. Proses ini dilakukan semasa aloi logam berada dalam keadaan separa pepejal. Proses pembentukan-tikso melibatkan proses pemanasan bahan suapan (aloi logam) sehingga satu suhu separa pepejal dan diikuti proses menekan masuk bahan suapan separa pepejal tersebut ke dalam acuan. Keperluan utama proses ini adalah bahan suapan yang mempunyai sifat tiksotropik. Semasa dalam keadaan separa pepejal, bahan suapan yang memiliki sifat tiksotropik akan berkelakuan seperti mentega iaitu mampu berdiri pegun seperti pepejal sekiranya dibiarkan dan sebaliknya akan mengalir seperti cecair apabila dikenakan daya ke atasnya (Arif et al. 2013; Kirkwood et al. 2010; Omar et al. 2011). Terdapat banyak kaedah yang telah dibangunkan untuk menghasilkan bahan suapan yang memiliki sifat tiksotropik, antaranya ialah proses tuangan cerun penyejuk. Proses tuangan cerun penyejuk melibatkan proses tuangan aloi logam di atas satu plat logam yang disejukkan dengan aliran air di bawahnya. Proses ini juga melibatkan beberapa parameter utama seperti suhu tuangan, panjang cerun penyejukan dan sudut kecondongan plat logam (Arif et al. 2018; Salleh et al. 2014).

Aloi aluminium-silikon-kuprum (Al-Si-Cu) adalah antara aloi logam yang banyak digunakan untuk proses 
pembentukan-tikso. Aloi ini menawarkan pelbagai kelebihan istimewa berbanding aloi logam yang lain seperti ringan, tahan karat dan mempunyai nisbah kekuatan terhadap ketumpatan yang tinggi (Chu et al. 2008; Daud et al. 2001; Othman et al. 2018; Salleh et al. 2018; Shamsudin et al. 2007). Aloi Al-Si-Cu digunakan untuk menggantikan besi tuang dalam menghasilkan komponen otomotif seperti rod penyambung, aci engkol dan aci sesondol. Sebagai panduan, gambarajah fasa untuk aloi Al-Si-Cu boleh diperoleh dalam ASM Handbook (2004). Liu et al. (2005) ada menyenaraikan kriteria kebolehbentukan-tikso untuk aloi Al. Pertama, titik 'lutut' tertinggi pada lengkung pecahan cecair melawan suhu sepatutnya berlaku dalam julat pecahan cecair $\left(\Delta f_{L}\right)$ antara 0.3 dan 0.5 . Julat pecahan cecair antara 0.3 dan 0.5 adalah julat pecahan cecair yang sesuai untuk proses pembentukantikso. Titik 'lutut' tertinggi di atas lengkung pecahan cecair melawan suhu adalah merujuk kepada suhu keseluruhan fasa eutektik habis melebur dan bermulanya peleburan fasa utama $\alpha$-Al. Semasa proses peleburan separa, fasa eutektik mesti dileburkan sepenuhnya tanpa meleburkan terlalu banyak fasa utama $\alpha$-Al. Oleh itu, proses peleburan separa perlu dilakukan pada suhu di atas titik 'lutut' tertinggi. Selain itu, pembentukan fasa cecair akan mudah dikawal sekiranya titik 'lutut' tertinggi berlaku dalam julat pecahan cecair antara 0.3 dan 0.5 kerana kadar pembentukan fasa cecair di atas titik 'lutut' tertinggi adalah lebih perlahan berbanding di bawahnya. Kedua, sensitiviti pecahan cecair $\left(d f_{L} / d T\right)$ di atas titik 'lutut' tertinggi mestilah serendah yang mungkin (kurang daripada $0.03{ }^{\circ} \mathrm{C}^{-1}$ ) supaya bahan suapan mudah dikendalikan apabila dipanaskan pada suhu separa pepejal. Sensitiviti pecahan cecair merujuk kepada kesan perubahan suhu terhadap pecahan cecair. Nilai sensitiviti pecahan cecair bergantung kepada keluasan 'tingkap pemprosesan' antara suhu pecahan cecair 0.3 dan 0.5 $\left(\Delta T_{0.3 / 0.5}\right)$. Semakin luas 'tingkap pemprosesan', semakin rendah nilai sensitiviti pecahan cecair. Bagi proses pembentukan-tikso, 'tingkap pemprosesan' minimum untuk pecahan cecair adalah antara 0.3 dan 0.5 adalah $6^{\circ} \mathrm{C}$. Ketiga, julat pemejalan $\left(\Delta T_{\text {sol. }}\right)$ aloi Al tidak boleh terlalu besar (tidak boleh melebihi $130^{\circ} \mathrm{C}$ ). Julat pemejalan ialah julat suhu antara sempadan pepejal dan sempadan cecair. Julat pemejalan yang terlalu besar boleh menyumbang kepada koyakan panas dan keporosan.

Sehingga kini, terdapat banyak laporan tentang uji kaji pembentukan-tikso yang dilakukan ke atas aloi Al. Namun, laporan tersebut hanya tertumpu kepada beberapa aloi $\mathrm{Al}$ tuang sahaja seperti A357, A356 dan A319. Oleh itu, usaha mencari dan membangunkan aloi Al yang sesuai untuk proses pembentukan-tikso perlu dilakukan supaya kemampuan proses ini dapat dipraktikkan. Pelbagai pakej perisian simulasi jangkaan termodinamik yang boleh digunakan untuk membangunkan komposisi kimia aloi Al yang dapat memenuhi kriteria kebolehbentukan-tikso seperti Thermo-Calc, ChemSage, MTDATA dan JMatPro. Pada tahun 2005, Liu et al. telah menerbitkan satu laporan mengenai kesan penambahan $\mathrm{Cu}$ dalam aloi A356 dan penambahan Si dalam aloi 2014 terhadap sifat kebolehbentukan-tikso aloi tersebut. Manakala, Maciel et al. (2003) pula mengkaji kesan unsur pengaloian dalam sistem aloi $\mathrm{Al}-\mathrm{Zn}-\mathrm{Mg}-\mathrm{Cu}$ terhadap perubahan pecahan cecair dan fasa keseimbangan yang wujud. Kedua-dua kajian tersebut dilakukan dengan menggunakan perisian MTDATA yang telah dibangunkan oleh National Physical Laboratory (NPL). Selain itu, Zoqui et al. (2016) pula mengkaji sifat kebolehbentukan-tikso aloi Al-Si dengan kandungan Si yang pelbagai dengan menggunakan perisian simulasi Thermo-Calc. Kajian ini signifikan kerana ia dilakukan bagi membangunkan satu komposisi kimia aloi Al yang sesuai untuk proses pembentukan-tikso melalui pengukuran kebolehbentukan-tikso aloi 2014 dengan penambahan $\mathrm{Si}$ dan pengurangan $\mathrm{Cu}$. Kriteria kebolehbentukan-tikso aloi 2014 dan aloi 2014-terubah suai dengan penambahan $\mathrm{Si}$ dan pengurangan $\mathrm{Cu}$ diukur secara simulasi menggunakan perisian JMatPro dan seterusnya dibuktikan dengan eksperimen melalui keduadua analisis terma dan fasa. Evolusi mikrostruktur aloi Al-terubah suai kesan daripada proses peleburan separa dan pembentukan-tikso juga diperhatikan.

\section{BAHAN DAN KAEDAH}

Permodelan sifat termodinamik dan fasa keseimbangan dilakukan untuk mengukur sifat kebolehbentukan-tikso aloi 2014 dan aloi 2014-terubah suai secara simulasi. Permodelan tersebut dibuat dengan menggunakan perisian JMatPro (Java-based Materials Properties software) yang telah dibangunkan oleh Sente Software Ltd. United Kingdom. Komposisi kimia aloi 2014 diubah suai dengan penambahan unsur $\mathrm{Si}$ dan pengurangan unsur $\mathrm{Cu}$. Seterusnya, bahan awal aloi Al-terubah suai dihasilkan melalui proses tuangan graviti berdasarkan komposisi kimia (Al-5Si-3Cu-0.5Mg-0.8Mn-0.7Fe-0.25Zn) yang telah diukur oleh perisian JMatPro. Komposisi kimia bahan awal tersebut disemak dengan menggunakan mesin X-Ray Fluorescence (XRF), jenama Bruker, model S8 Tiger.

Analisis terma dilakukan ke atas sampel bahan awal aloi Al-terubah suai dengan menggunakan mesin kalorimetri imbasan kebezaan (DSC) jenis Netzsch-STA (TG-DSC) 449 F3 dan dibandingkan dengan hasil simulasi yang diukur oleh JMatPro. Analisis ini dilakukan untuk menentukan perubahan kapasiti haba terhadap suhu. Perubahan kapasiti haba terhadap suhu ditentukan dengan mengukur haba yang mengalir masuk atau diserap ke dalam sampel semasa pemanasan. Bahan awal aloi Al-terubah suai dipotong kepada butiran kecil (berat kurang daripada $20 \mathrm{mg}$ ) untuk dijadikan sampel dan diletakkan di dalam bekas $\mathrm{Al}_{2} \mathrm{O}_{3}$ sebelum ditempatkan di atas platform mesin DSC. Sampel tersebut dipanaskan daripada suhu bilik $\left(37^{\circ} \mathrm{C}\right)$ sehingga mencapai suhu penguraian $\left(697^{\circ} \mathrm{C}\right)$ dengan kadar pemanasan $2.5^{\circ} \mathrm{C} /$ minit. Pemanasan dijalankan dalam atmosfera nitrogen untuk mengelakkan pengoksidaan. Aliran haba yang diserap diukur dengan termogandingan dan direkod menggunakan perisian NETZSCH Proteus. Seterusnya, profil pecahan cecair 
melawan suhu ditentukan berdasarkan kamiran luas di atas lengkung aliran haba melawan suhu.

Analisis fasa dilakukan ke atas sampel bahan awal aloi Al-terubah suai untuk mengenal pasti fasa yang wujud. Analisis fasa dilakukan dengan menggunakan mesin pembelauan sinar-X (XRD) jenama Bruker (D8-Advance) dengan radiasi $\mathrm{Cu}-\mathrm{K}_{\alpha}$ berturas nikel pada kadar imbasan $2 \%$ min, berjarak gelombang $1.5406 \AA$ dan sudut belauan $2 \theta$.

Bilet aloi Al-terubah suai dengan mikrostruktur bukandendrit dihasilkan melalui proses tuangan cerun penyejuk. Seterusnya, bilet tersebut dipanaskan semula sehingga suhu separa pepejalnya pada suhu $575^{\circ} \mathrm{C}$ sebelum ditekan masuk ke dalam acuan keluli dengan menggunakan mesin penekan hidraulik. Analisis mikrostruktur dilakukan dengan menggunakan mikroskop optik jenis Olympus ke atas sampel yang telah dicanai, digilap dan dipunar dengan larutan Keller.

\section{KePutusan dan Perbincangan}

\section{JANGKAAN TERMODINAMIK}

Rajah 1 menunjukkan graf pecahan cecair melawan suhu yang diperoleh daripada hasil jangkaan simulasi ke atas komposisi kimia aloi 2014 dan aloi 2014-terubah suai dengan kandungan Si yang pelbagai. Lengkung garis putusputus berwarna hitam mewakili jangkaan untuk hubungan pecahan cecair melawan suhu bagi aloi 2014 (Al-0.8Si$4.5 \mathrm{Cu}-0.5 \mathrm{Mg}-0.8 \mathrm{Mn}-0.7 \mathrm{Fe}-0.25 \mathrm{Zn}$ ). Lengkung tersebut menunjukkan bahawa aloi 2014 memiliki julat pemejalan $\left(\Delta T_{\text {sol. }}\right)$ yang terlalu besar iaitu dianggarkan lebih kurang $132^{\circ} \mathrm{C}$ dan pecahan cecair pada titik 'lutut' tertinggi yang terlalu rendah iaitu 0.09 pecahan cecair. Oleh itu, aloi 2014 tidak dapat memenuhi kriteria kebolehbentukan-tikso yang telah dinyatakan.

Komposisi kimia aloi 2014 diubah suai dengan penambahan kandungan Si sehingga $5 \%$ bt. Di samping menawarkan sifat kebolehtuangan yang baik, penambahan Si juga mampu mengurangkan julat pemejalan dan meningkatkan pecahan cecair pada titik 'lutut' tertinggi (meningkatkan kandungan fasa eutektik dalam struktur aloi Al). Hasil jangkaan simulasi menunjukkan bahawa julat pemejalan berkurang dan pecahan cecair pada titik 'lutut' tertinggi meningkat dengan ketara selepas kandungan Si dalam komposisi kimia aloi 2014 bertambah. Apabila kandungan Si dalam komposisi kimia aloi 2014 bertambah daripada 0.8 kepada $5 \%$ bt, julat pemejalan $\left(\Delta T_{\text {sol. }}\right)$ berkurang daripada $132^{\circ} \mathrm{C}$ kepada $106^{\circ} \mathrm{C}$, manakala pecahan cecair pada titik 'lutut' tertinggi pula meningkat daripada 0.09 kepada 0.42 pecahan cecair. Oleh itu, aloi 2014-terubah suai dengan penambahan sehingga $5 \%$ bt. Si (Al-5Si-4.5Cu-0.5Mg-0.8Mn-0.7Fe-0.25Zn) dijangka mempunyai sifat kebolehbentukan-tikso yang lebih baik berbanding aloi 2014.

Penambahan Cu dalam aloi Al-Si boleh meningkatkan kekuatan bahan dengan ketara dan menggalakkan berlakunya proses pemendakan pengerasan akibat daripada pembentukan fasa $\mathrm{Al}_{2} \mathrm{Cu}$ dan sebatian antara logam yang lain (Sadeghi et al. 2017). Bagaimanapun, penambahan unsur $\mathrm{Cu}$ boleh menyebabkan kemuluran aloi $\mathrm{Al}$ berkurang serta rintangan karatan dan koyakan panas semakin lemah. Selain itu, penambahan $\mathrm{Cu}$ juga boleh mengurangkan sifat kebolehtuangan aloi Al (Mondolfo 1976). Oleh itu, jangkaan sifat termodinamik diteruskan bagi mengkaji kesan pengurangan $\mathrm{Cu}$ pada sifat kebolehbentukan-tikso aloi 2014-terubah suai dengan penambahan sehingga $5 \%$ bt. Si. Rajah 2 menunjukkan perubahan ke atas julat pemejalan $\left(\Delta T_{\text {sol }}\right)$, pecahan cecair pada titik 'lutut' tertinggi

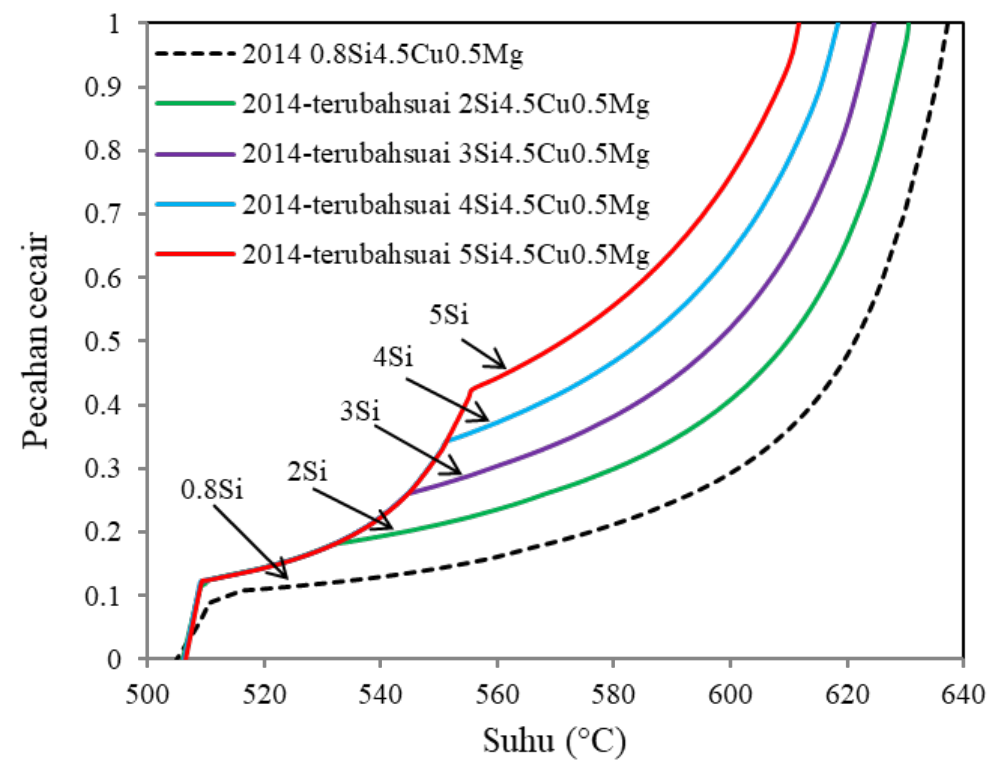

RAJAH 1. Graf pecahan cecair melawan suhu untuk aloi 2014 dan aloi 2014-terubah suai dengan kandungan Si yang pelbagai; dihitung menggunakan perisian simulasi JMatPro 
dan tingkap pemprosesan antara pecahan cecair 0.3 dan 0.5 $\left(\Delta T_{0.3 / 0.5}\right)$ akibat pengurangan kandungan $\mathrm{Cu}$ dalam aloi 2014-terubah suai dengan penambahan sehingga $5 \%$ bt. Si (Al-5Si-4.5Cu-0.5Mg-0.8Mn-0.7Fe-0.25Zn). Hasil jangkaan simulasi mendapati bahawa apabila kandungan $\mathrm{Cu}$ dikurangkan daripada 4.5 kepada $3 \%$ bt., julat pemejalan $\left(\Delta T_{\text {sol. }}\right)$ bertambah daripada $106^{\circ} \mathrm{C}$ kepada $111^{\circ} \mathrm{C}$ dan pecahan cecair pada titik 'lutut' tertinggi berkurang daripada 0.42 kepada 0.39 pecahan cecair. Pada masa yang sama, 'tingkap pemprosesan' antara pecahan cecair 0.3 dan $0.5\left(\Delta T_{0.3 / 0.5}\right)$ menjadi semakin luas iaitu meningkat daripada $20^{\circ} \mathrm{C}$ kepada $25^{\circ} \mathrm{C}$ lalu menjadikan sensitiviti pecahan cecair $\left(d f_{L} / d T\right)$ di atas titik 'lutut' tertinggi berkurang daripada 0.006 kepada $0.004{ }^{\circ} \mathrm{C}^{-1}$. Di samping dapat memenuhi kriteria kebolehbentukan-tikso, aloi 2014-terubah suai dengan kandungan $5 \%$ bt. Si dan $3 \%$ bt. $\mathrm{Cu}$ (Al-5Si-3Cu-0.5Mg-0.8Mn-0.7Fe-0.25Zn) juga dijangkakan memiliki sifat mekanik yang baik. Oleh itu, aloi Al-terubah suai ini sangat sesuai untuk proses pembentukan-tikso. Parameter pemejalan yang diperoleh daripada hasil permodelan termodinamik JMatPro untuk aloi 2014 dan aloi 2014-terubah suai dengan penambahan $\mathrm{Si}$ dan pengurangan $\mathrm{Cu}$ yang diterangkan sebelum ini ada dinyatakan dalam Jadual 1.

Rajah 3 menunjukkan gambarajah fasa keseimbangan untuk aloi 2014, aloi 2014-terubah suai dengan $5 \%$ bt. Si, dan aloi 2014-terubah suai dengan $5 \%$ bt. Si dan $3 \%$ bt. $\mathrm{Cu}$ (aloi Al-terubah suai) yang dihitung oleh perisian JMatPro. Fasa yang wujud dalam ketiga-tiga aloi tersebut adalah $\mathrm{Si}, \mathrm{Al}_{2} \mathrm{Cu}, \beta-\mathrm{Al}_{5} \mathrm{FeSi}$ dan $\theta-\mathrm{Al}_{5} \mathrm{Cu}_{2} \mathrm{Mg}_{8} \mathrm{Si}_{6}$. Manakala wujud satu lagi fasa lain iaitu $\pi-\mathrm{Al}_{8} \mathrm{FeMg}_{3} \mathrm{Si}_{6}$ dalam aloi Al-terubah suai. Kewujudan fasa-fasa tersebut adalah disebabkan oleh penambahan unsur-unsur $\mathrm{Si}, \mathrm{Cu}$, magnesium $(\mathrm{Mg})$ dan ferum $(\mathrm{Fe})$ dalam Aloi Al.

Menurut Sjölander dan Seifeddine (2010), transformasi fasa $\pi-\mathrm{Al}_{8} \mathrm{FeMg}_{3} \mathrm{Si}_{6}$ daripada fasa $\beta-\mathrm{Al}_{5} \mathrm{FeSi}$ terjadi apabila kandungan $\mathrm{Mg}$ dalam aloi $\mathrm{Al}-\mathrm{Si}-\mathrm{Cu}-\mathrm{Mg}$ mencapai $0.35 \%$ bt. Peratusan berat fasa $\pi-\mathrm{Al}_{8} \mathrm{FeMg}_{3} \mathrm{Si}_{6}$ meningkat dengan

JADUAL 1. Parameter pemejalan aloi 2014 dan aloi 2014-terubah suai; dihitung oleh perisian simulasi JMatPro

\begin{tabular}{lcccccc}
\hline Aloi aluminium & $T_{l}\left({ }^{\circ} \mathrm{C}\right)$ & $T_{s}\left({ }^{\circ} \mathrm{C}\right)$ & $\Delta T_{s o l} .\left({ }^{\circ} \mathrm{C}\right)$ & Kandungan eutektik & $\Delta T_{0.3 / 0.5}\left({ }^{\circ} \mathrm{C}\right)$ & $\mathrm{d} f_{L} / \mathrm{d} T\left({ }^{\circ} \mathrm{C}-1\right)$ \\
\hline 2014 0.8Si4.5Cu0.5Mg & 637 & 505 & 132 & 0.09 & 22 & 0.001 \\
2014-terubah suai 2Si4.5Cu0.5Mg & 630 & 506 & 124 & 0.17 & 30 & 0.001 \\
2014-terubah suai 3Si4.5Cu0.5Mg & 625 & 506 & 119 & 0.26 & 35 & 0.003 \\
2014-terubah suai 4Si4.5Cu0.5Mg & 618 & 506 & 112 & 0.34 & 35 & 0.004 \\
2014-terubah suai 5Si4.5Cu0.5Mg & 612 & 506 & 106 & 0.42 & 20 & 0.006 \\
2014-terubah suai 5Si4.0Cu0.5Mg & 613 & 509 & 104 & 0.41 & 25 & 0.006 \\
2014-terubah suai 5Si3.5Cu0.5Mg & 615 & 500 & 115 & 0.40 & 27 & 0.005 \\
2014-terubah suai 5Si3.0Cu0.5Mg & 616 & 505 & 111 & 0.39 & 25 & 0.004 \\
\hline
\end{tabular}

$T_{l}$ ialah suhu sempadan cecair; $T_{s}$ ialah suhu sempadan pepejal; $\Delta T_{\text {sol }}$ ialah julat suhu pemejalan; $\Delta T_{0.30 .5}$ ialah julat suhu di antara pecahan cecair 0.3 dan $0.5 ; \mathrm{d} f_{L} / \mathrm{d} T$ ialah sensitiviti pecahan cecair

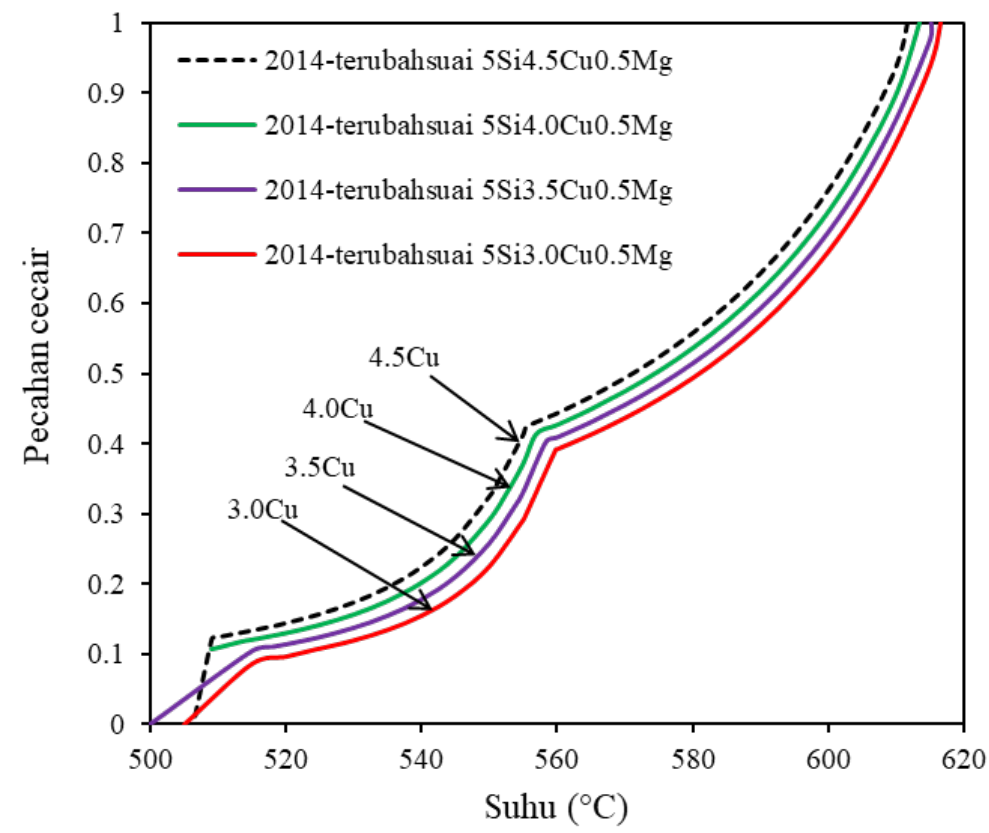

RAJAH 2. Lengkung pecahan cecair melawan suhu untuk aloi 2014-terubah suai dengan penambahan sehingga $5 \%$ bt. Si dan kandungan $\mathrm{Cu}$ yang pelbagai; dihitung menggunakan perisian simulasi JMatPro 

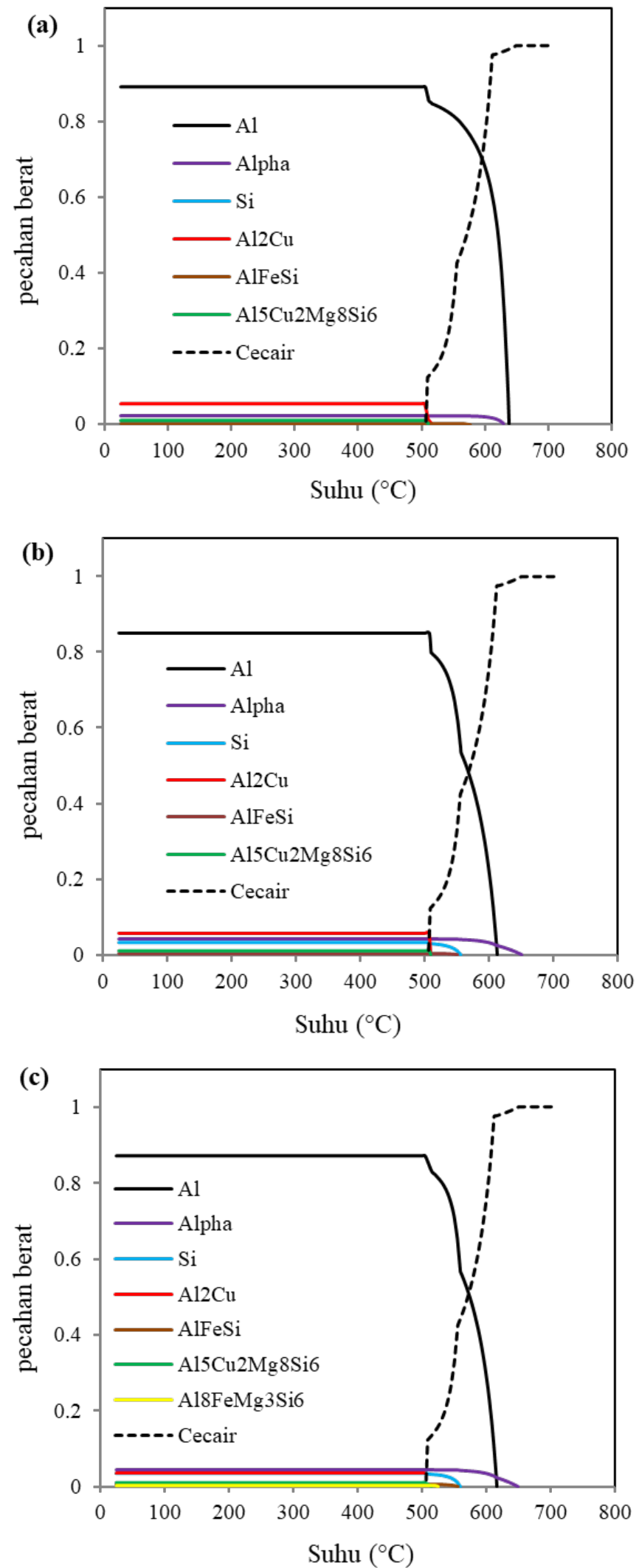

RAJAH 3. Gambarajah fasa keseimbangan (a) aloi 2014, (b) aloi 2014-terubah suai dengan $5 \%$ bt. Si, dan (c) aloi Al-terubah suai dengan $5 \%$ bt. Si dan $3 \%$ bt. Cu; dihitung menggunakan perisian simulasi JMatPro 
JADUAL 2. Pecahan berat untuk setiap fasa yang wujud dalam aloi 2014, aloi 2014-terubah suai dengan 5 \% bt. Si dan aloi Alterubah suai dengan $5 \%$ bt. Si dan $3 \%$ bt. Cu; dihitung menggunakan perisian simulasi JMatPro

\begin{tabular}{|c|c|c|c|c|c|}
\hline \multirow{2}{*}{ Aloi aluminium } & \multicolumn{5}{|c|}{ Pecahan berat fasa } \\
\hline & $\mathrm{Si}$ & $\mathrm{A} 12 \mathrm{Cu}$ & $\beta$ & $\theta$ & $\pi$ \\
\hline Aloi $20140.8 \mathrm{Si} 4.5 \mathrm{Cu} 0.5 \mathrm{Mg}$ & 0.001 & 0.05 & 0.001 & 0.008 & 0 \\
\hline Aloi 2014-terubah suai $5 \mathrm{Si} 4.5 \mathrm{Cu} 0.5 \mathrm{Mg}$ & 0.03 & 0.06 & 0.004 & 0.01 & 0 \\
\hline Aloi Al-terubah suai $5 \mathrm{Si} 3.0 \mathrm{Cu} 0.5 \mathrm{Mg}$ & 0.03 & 0.03 & 0.004 & 0.009 & 0.002 \\
\hline
\end{tabular}

JADUAL 3. Komposisi kimia aloi Al-terubah suai (\% bt.)

\begin{tabular}{lccccccc}
\hline & $\mathrm{Si}$ & $\mathrm{Cu}$ & $\mathrm{Mg}$ & $\mathrm{Zn}$ & $\mathrm{Mn}$ & $\mathrm{Fe}$ & $\mathrm{Al}$ \\
\hline Aloi Al-terubah suai (JMatPro) & 5.0 & 3.0 & 0.5 & 0.25 & 0.8 & 0.7 & $\mathrm{Baki}$ \\
Aloi Al-terubah suai (XRF) & 4.78 & 2.76 & 0.48 & - & 0.14 & 0.45 & $\mathrm{Baki}$ \\
\hline
\end{tabular}

bertambahnya kandungan Mg. Bagaimanapun, kajian ini mendapati bahawa fasa $\pi-\mathrm{Al}_{8} \mathrm{FeMg}_{3} \mathrm{Si}_{6}$ tidak wujud dalam kedua-dua aloi 2014 dan aloi 2014-terubah suai dengan penambahan Si sehingga $5 \%$ bt. walaupun kandungan $\mathrm{Mg}$ melebihi $0.35 \%$ bt. (0.5 \% bt.). Fasa $\pi-\mathrm{Al}_{8} \mathrm{FeMg}_{3} \mathrm{Si}_{6}$ hanya muncul dalam aloi Al-terubah suai dengan $5 \%$ bt. Si dan 3 $\%$ bt. $\mathrm{Cu}$ iaitu apabila kandungan $\mathrm{Cu}$ dikurangkan kepada $3 \%$ bt. Keadaan ini menunjukkan bahawa kewujudan fasa $\pi-\mathrm{Al}_{8} \mathrm{FeMg}_{3} \mathrm{Si}_{6}$ dalam aloi $\mathrm{Al}-\mathrm{Si}-\mathrm{Cu}-\mathrm{Mg}$ tidak hanya bergantung kepada kandungan $\mathrm{Mg}$ tetapi dipengaruhi juga oleh kandungan $\mathrm{Cu}$. $\theta-\mathrm{Al}_{5} \mathrm{Cu}_{2} \mathrm{Mg}_{8} \mathrm{Si}_{6}$ dan $\pi-\mathrm{Al}_{8} \mathrm{FeMg}_{3} \mathrm{Si}_{6}$ adalah fasa yang mengandungi unsur $\mathrm{Mg}$ yang dapat meningkatkan sifat mekanik aloi Al. Zuo et al. (2017) mendapati bahawa kekuatan tegangan muktamad (UTS) aloi Al-Si-Cu-Mg pada suhu tinggi $\left(250^{\circ} \mathrm{C}\right)$ bertambah daripada $157 \mathrm{MPa}$ kepada $199 \mathrm{MPa}$ apabila pecahan isi padu fasa $\theta-\mathrm{Al}_{5} \mathrm{Cu}_{2} \mathrm{Mg}_{8} \mathrm{Si}_{6}$ bertambah daripada $3.2 \%$ kepada $6.4 \%$. Farkoosh dan Pekguleryuz (2015) juga menyatakan bahawa fasa $\theta-\mathrm{Al}_{5} \mathrm{Cu}_{2} \mathrm{Mg}_{8} \mathrm{Si}_{6}$ adalah stabil secara termodinamik dalam aloi Al-Si-Cu-Mg dan bertaburan dalam matriks Al. Di samping itu, Alkhawari et al. (2017) pula menyatakan bahawa fasa $\pi$ - $\mathrm{Al}_{8} \mathrm{FeMg}_{3} \mathrm{Si}_{6}$ adalah keras dan mempunyai rintangan yang tinggi terhadap lekukan. Morfologi fasa $\theta-\mathrm{Al}_{5} \mathrm{Cu}_{2} \mathrm{Mg}_{8} \mathrm{Si}_{6}$ dan fasa $\pi-\mathrm{Al}_{8} \mathrm{FeMg}_{3} \mathrm{Si}_{6}$ adalah berbentuk mirip-skrip-cina atau seperti blok, manakala $\beta-\mathrm{Al}_{5} \mathrm{FeSi}$ pula terdiri daripada struktur yang tajam dan seperti plat. Struktur $\beta-\mathrm{Al}_{5} \mathrm{FeSi}$ yang tajam dan seperti plat boleh menyebabkan sifat mekanik aloi Al berkurang. Namun, fasa $\theta-\mathrm{Al}_{5} \mathrm{Cu}_{2} \mathrm{Mg}_{8} \mathrm{Si}_{6}$ dan fasa $\pi-\mathrm{Al}_{8} \mathrm{FeMg}_{3} \mathrm{Si}_{6}$ pula kurang menjejaskan sifat mekanik aloi berbanding $\beta-\mathrm{Al}_{5} \mathrm{FeSi}$ disebabkan morfologinya yang padat.
Berdasarkan gambarajah fasa keseimbangan dalam Rajah 3, pecahan berat bagi kedua-dua fasa Si dan $\beta-\mathrm{Al}_{5} \mathrm{FeSi}$ dalam aloi 2014 adalah 0.001. Pecahan berat fasa $\mathrm{Si}$ dan fasa $\beta-\mathrm{Al}_{5} \mathrm{FeSi}$ masing-masing meningkat kepada 0.03 dan 0.004 apabila kandungan Si dalam aloi 2014 bertambah daripada 0.8 kepada $5 \%$ bt. Seterusnya, pecahan berat fasa $\mathrm{Al}_{2} \mathrm{Cu}$ dalam aloi 2014 adalah 0.05 dan menurun kepada 0.03 apabila kandungan $\mathrm{Cu}$ dikurangkan daripada 4.5 kepada $3 \%$ bt. Bagi fasa $\theta-\mathrm{Al}_{5} \mathrm{Cu}_{2} \mathrm{Mg}_{8} \mathrm{Si}_{6}$, pecahan beratnya tidak menunjukkan perubahan yang ketara (daripada 0.008 kepada 0.009) dengan penambahan kandungan $\mathrm{Si}$ dan pengurangan $\mathrm{Cu}$. Manakala, fasa $\pi-\mathrm{Al}_{8} \mathrm{FeMg}_{3} \mathrm{Si}_{6}$ (dengan pecahan berat 0.002 ) hanya wujud dalam aloi Al-terubah suai dengan $5 \%$ bt. Si dan $3 \%$ bt. $\mathrm{Cu}$. Jadual 2 ada menyenaraikan pecahan berat untuk setiap fasa bagi aloi 2014 dan aloi 2014-terubah suai dengan penambahan $\mathrm{Si}$ dan pengurangan $\mathrm{Cu}$.

\section{HaSIL UJI KaJI}

Jadual 3 menyenaraikan komposisi kimia bahan awal aloi Al-terubah suai yang telah disemak oleh mesin XRF. Sebagai perbandingan, komposisi kimia aloi Al-terubah suai yang telah diukur oleh perisian JMatPro yang dijadikan panduan untuk menghasilkan bahan awal aloi Al-terubah suai juga turut disenaraikan bersama.

Rajah 4 menunjukkan perbandingan antara lengkung pemanasan (aliran haba melawan suhu) berserta lengkung taburan cecairnya (pecahan cecair melawan suhu) yang sepadan hasil daripada analisis terma DSC ke atas sampel bahan awal aloi Al-terubah suai dan lengkung pecahan

JADUAL 4. Perbandingan parameter pemejalan aloi Al-terubah suai yang diperoleh daripada JMatPro dan DSC

\begin{tabular}{lcccccc}
\hline Aloi aluminium & $T_{l}\left({ }^{\circ} \mathrm{C}\right)$ & $T_{s}\left({ }^{\circ} \mathrm{C}\right)$ & $\Delta T_{\text {sol }}\left({ }^{\circ} \mathrm{C}\right)$ & Kandungan eutektik & $\Delta T_{0.3 / 0.5}\left({ }^{\circ} \mathrm{C}\right)$ & $\mathrm{d} f_{L} / \mathrm{d} T\left({ }^{\circ} \mathrm{C}-1\right)$ \\
\hline Aloi Al-terubah suai (JMatPro) & 616 & 505 & 111 & 0.39 & 25 & 0.004 \\
Aloi Al-terubah suai (DSC) & 629 & 501 & 128 & 0.33 & 31 & 0.003 \\
\hline
\end{tabular}

$T_{l}$ ialah suhu sempadan cecair; $T_{s}$ ialah suhu sempadan pepejal; $\Delta T_{\text {sol }}$ ialah julat suhu pemejalan; $\Delta T_{0.3 / 0.5}$ ialah julat suhu di antara pecahan cecair 0.3 dan $0.5 ; \mathrm{d} f_{L} / \mathrm{d} T$ ialah sensitiviti pecahan cecair 


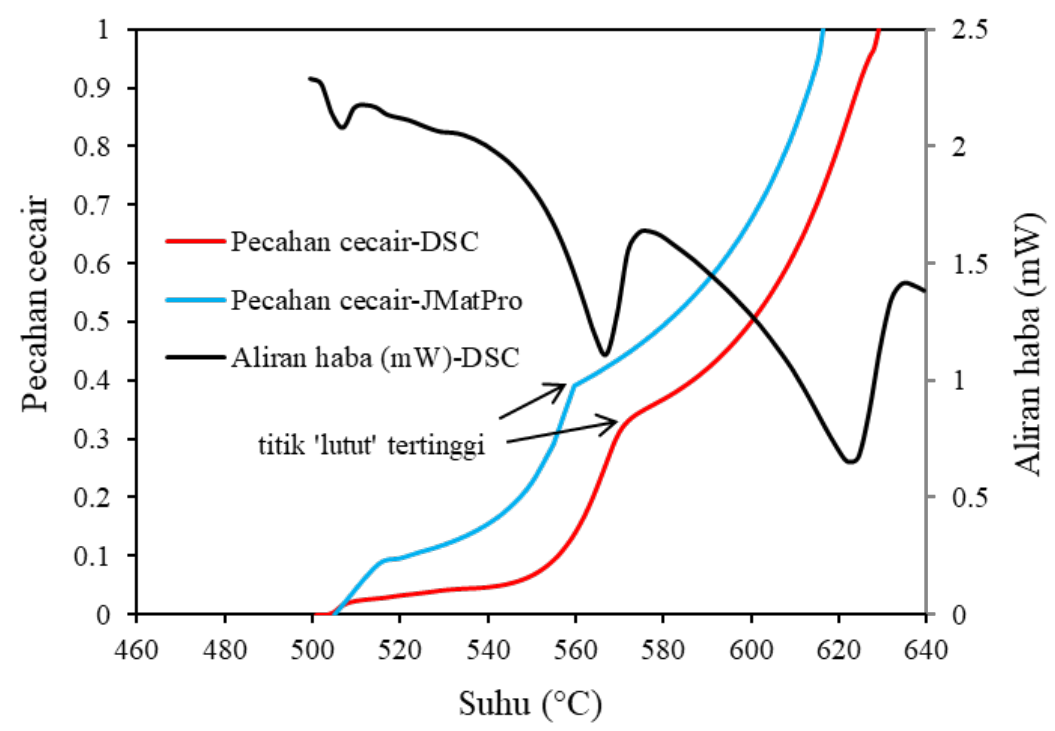

RAJAH 4. Lengkung pecahan cecair DSC berserta aliran habanya yang sepadan dan lengkung pecahan cecair JMatPro untuk aloi Al-terubah suai

cecair melawan suhu hasil daripada simulasi perisian JMatPro. Dapat diperhatikan bahawa titik 'lutut' tertinggi yang diperoleh daripada analisis terma DSC berlaku pada suhu yang lebih tinggi daripada hasil jangkaan simulasi JMatPro. Kedudukan titik 'lutut' tertinggi untuk lengkung DSC berlaku pada suhu $572^{\circ} \mathrm{C}$, manakala untuk lengkung JMatPro pula ialah pada suhu $560^{\circ} \mathrm{C}$. Pecahan cecair pada titik 'lutut' tertinggi adalah dianggarkan sebanyak 0.33 untuk lengkung DSC dan 0.39 untuk lengkung JMatPro. Sensitiviti pecahan cecair $\left(d f_{L} / d T\right)$ di atas titik 'lutut' tertinggi bagi lengkung DSC adalah bersamaan $0.003{ }^{\circ} \mathrm{C}^{-1}$ dan bagi lengkung JMatPro ialah $0.004{ }^{\circ} \mathrm{C}^{-1}$. Julat suhu pemejalan yang diperoleh daripada analisis DSC ialah $128^{\circ} \mathrm{C}$ dan yang dihitung oleh JMatPro ialah $111^{\circ} \mathrm{C}$. Manakala, ‘tingkap pemprosesan' antara pecahan cecair 0.3 dan $0.5\left(\Delta T_{0.3-0.5}\right)$ untuk lengkung DSC ialah $31^{\circ} \mathrm{C}$ dan untuk lengkung JMatPro ialah $25^{\circ} \mathrm{C}$. Jadual 4 menyenaraikan parameter pemejalan yang diperoleh daripada analisis terma DSC dan jangkaan simulasi JMatPro untuk aloi Al-terubah suai. Berdasarkan parameter pemejalan yang diperoleh daripada analisis terma DSC, aloi Al-terubah suai terbukti dapat memenuhi kriteria kebolehbentukan-tikso dan sangat sesuai untuk proses pembentukan-tikso.

Perbezaan antara hasil yang diperoleh daripada DSC dan JMatPro adalah disebabkan oleh beberapa faktor iaitu jangkaan simulasi mempertimbangkan komposisi kimia yang ideal (uji kaji yang sempurna), manakala analisis secara uji kaji pula melibatkan komposisi kimia yang tidak sekata disebabkan taburan unsur pengaloian yang tidak seragam serta mengambil kira bendasing yang terkandung dalam jongkong aloi. Di samping itu, pengiraan yang dibuat oleh proses simulasi mempertimbangkan komposisi satu bahan yang besar, manakala ujian DSC pula dilakukan ke

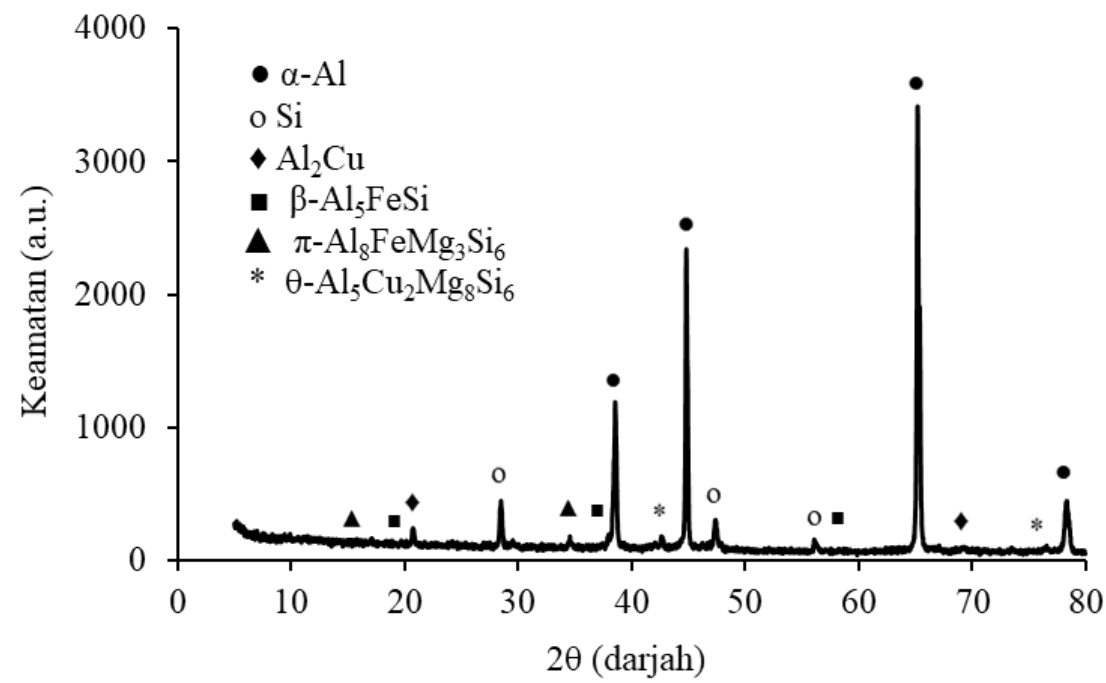

RAJAH 5. Corak XRD untuk aloi Al-terubah suai dengan $5 \%$ bt. Si dan $3 \%$ bt. Cu 
atas sebahagian kecil sampel (berat kurang daripada 20 $\mathrm{mg}$ ) yang diambil daripada jongkong aloi yang besar. Faktor kinetik juga menyebabkan kedudukan titik 'lutut' tertinggi lengkung DSC berlaku di bawah pecahan cecair titik 'lutut' tertinggi lengkung JMatPro. Faktor kinetik adalah merujuk kepada kadar pemanasan sampel semasa uji kaji DSC (Liu et al. 2005).

Rajah 5 menunjukkan corak XRD yang diperoleh daripada analisis fasa bagi mengenal pasti fasa yang wujud dalam aloi Al-terubah suai. Corak XRD tersebut menunjukkan kemunculan fasa $\alpha$-Al dan Si eutektik yang merupakan unsur utama dalam aloi Al-terubah suai. Fasa ini ditandakan pada puncak yang mempunyai nilai keamatan yang tinggi pada pelbagai sudut. Di samping itu, corak XRD tersebut juga membuktikan kemunculan sebatian antara logam yang mengandungi unsur $\mathrm{Cu}$ iaitu $\mathrm{Al}_{2} \mathrm{Cu}$ dan $\theta-\mathrm{Al}_{5} \mathrm{Cu}_{2} \mathrm{Mg}_{8} \mathrm{Si}_{6}$, dan sebatian antara logam yang kaya dengan Fe iaitu $\beta-\mathrm{Al}_{5} \mathrm{FeSi}$ dan $\pi-\mathrm{Al}_{8} \mathrm{FeMg}_{3} \mathrm{Si}_{6}$.
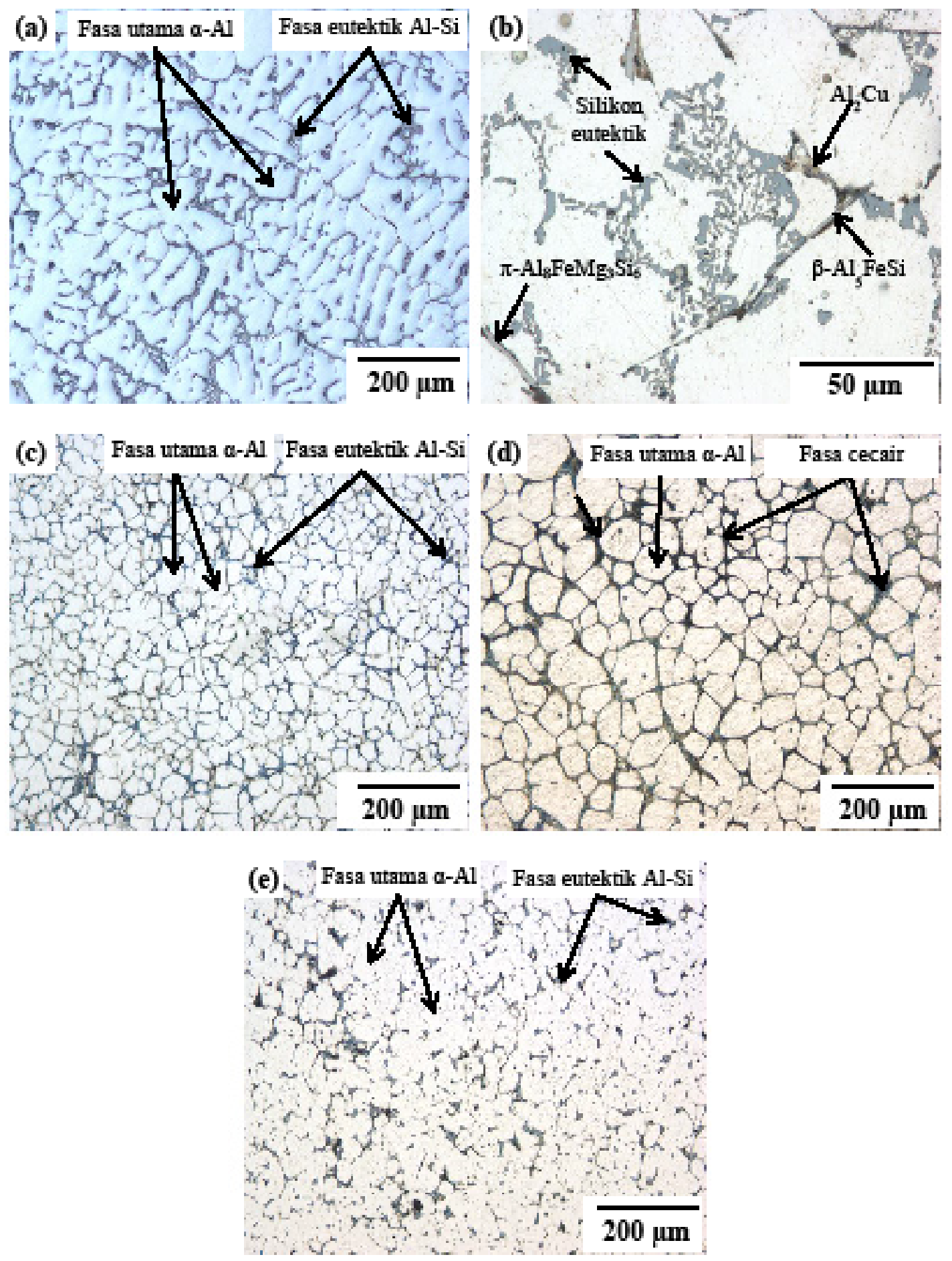

RAJAH 6. Mikrostruktur aloi Al-terubah suai dengan $5 \%$ bt. Si dan $3 \%$ bt. Cu (a) bahan awal, (b) sampel (a) dengan pembesaran yang lebih tinggi, (c) selepas tuangan cerun penyejuk, (d) selepas peleburan separa, dan (e) selepas dibentuk-tikso 
Rajah 6 menunjukkan evolusi mikrostruktur aloi Alterubah suai hasil daripada pemprosesan logam separa pepejal. Mikrostruktur tersebut membuktikan kesesuaian dan keupayaan aloi Al-terubah suai untuk proses pembentukan-tikso. Rajah 6(a) dan Rajah 6(b) mewakili mikrostruktur bahan awal aloi Al-terubah suai (dengan pembesaran yang berbeza) yang dihasilkan melalui proses tuangan graviti. Rajah 6(a) menunjukkan bahawa mikrostruktur bahan awal terdiri daripada struktur fasa utama $\alpha$-Al (berwarna cerah) yang berbentuk dendrit dan struktur antara dendrit fasa eutektik Al-Si (berwarna gelap). Manakala, Rajah 6(b) pula menunjukkan fasa yang muncul dalam aloi Al-terubah suai bagi membuktikan hasil jangkaan fasa keseimbangan melalui proses simulasi. Bagaimanapun, struktur dendrit perlu diubah kepada bentuk bukan-dendrit terlebih dahulu supaya mikrostruktur separa pepejal yang terdiri daripada struktur berbentuk hampir sfera dapat dihasilkan. Selepas proses tuangan cerun penyejuk dilakukan, bentuk mikrostruktur aloi Alterubah suai berubah daripada dendrit kepada bukandendrit (roset) yang halus seperti yang ditunjukkan dalam Rajah 6(c). Apabila bilet aloi Al-terubah suai yang mengandungi mikrostruktur bukan-dendrit seperti yang ditunjukkan dalam Rajah 6(c) dipanaskan semula sehingga suhu separa pepejalnya $\left(575^{\circ} \mathrm{C}\right)$, mikrostruktur separa pepejal yang terdiri daripada struktur fasa pepejal berbentuk hampir sfera dalam matriks cecair berjaya dihasilkan (Rajah 6(d)). Seterusnya, Rajah 6(e) menunjukkan mikrostruktur aloi Al-terubah suai yang terbentuk-tikso hasil daripada proses pembentukan-tikso ke atas bilet aloi Al-terubah suai yang berada dalam keadaan separa pepejal. Mikrostruktur tersebut menunjukkan bahawa struktur globular fasa utama $\alpha$-Al mengalami perubahan bentuk kesan daya mampatan yang dikenakan semasa proses pembentukan-tikso.

\section{KESIMPULAN}

Berdasarkan kajian ini, dapat disimpulkan bahawa aloi 2014 adalah tidak sesuai untuk proses pembentukan-tikso kerana kandungan fasa eutektik pada titik 'lutut' tertingginya yang terlalu rendah dan julat pemejalannya yang terlalu besar. Apabila kandungan Si dalam aloi 2014 ditambah, kandungan fasa eutektik pada titik 'lutut' tertingginya didapati meningkat dan julat suhu pemejalannya pula berkurang dengan ketara. Seterusnya, tingkap pemprosesan proses pembentukan-tikso menjadi bertambah luas dan sensitiviti pecahan cecair di atas titik 'lutut' tertinggi pula berkurang dengan pengurangan kandungan $\mathrm{Cu}$. Oleh itu, aloi Al-terubah suai (Al-5Si-3Cu-0.5Mg$0.8 \mathrm{Mn}-0.7 \mathrm{Fe}-0.25 \mathrm{Zn})$ dijangka memiliki sifat kebolehbentukan-tikso yang baik dan sesuai digunakan untuk proses pembentukan-tikso.

Di samping itu, dapat disimpulkan juga bahawa penambahan unsur Si ke dalam aloi 2014 mengakibatkan pecahan berat fasa Si eutektik meningkat. Peningkatan pecahan berat fasa Si eutektik boleh menyebabkan sifat kebolehtuangan aloi bertambah baik. Selain itu, kajian ini juga mendapati bahawa fasa $\pi-\mathrm{Al}_{8} \mathrm{FeMg}_{3} \mathrm{Si}_{6}$ boleh muncul dalam aloi Al-terubah suai hasil daripada pengurangan $\mathrm{Cu}$. Selain fasa $\mathrm{Al}_{2} \mathrm{Cu}$ dan $\theta-\mathrm{Al}_{5} \mathrm{Cu}_{2} \mathrm{Mg}_{8} \mathrm{Si}_{6}$, kewujudan fasa $\pi-\mathrm{Al}_{8} \mathrm{FeMg}_{3} \mathrm{Si}_{6}$ yang mempunyai bentuk struktur yang padat juga dijangka dapat meningkatkan sifat mekanik aloi Al-terubah suai.

\section{PENGHARGAAN}

Ucapan terima kasih ditujukan kepada Universiti Kebangsaan Malaysia dan Kementerian Pendidikan Malaysia yang telah memberikan tajaan untuk menjalankan kajian ini melalui geran penyelidikan DIP-2016-007.

\section{RUJUKAN}

Alhawari, K.S., Omar, M.Z., Ghazali, M.J., Salleh, M.S. \& Mohammed, M.N. 2017. Microstructural evolution during semisolid processing of Al-Si-Cu alloy with different $\mathrm{Mg}$ contents. Transactions of Nonferrous Metals Society of China 27(7): 1483-1497.

Arif, M.A.M., Omar, M.Z. \& Sajuri, Z. 2018. Pembentukan mikrostruktur berbentuk sfera dalam keadaan separa pepejal aloi aluminium Al-4.8Si-2.8Cu-0.5Mg. Jurnal Kejuruteraan 30(2): 275-280.

Arif, M.A.M., Omar, M.Z., Muhamad, N., Syarif, J. \& Kapranos, P. 2013. Microstructural evolution of solid-solution-treated $\mathrm{Zn}-22 \mathrm{Al}$ in the semisolid state. Journal of Materials Science \& Technology 29(8): 765-774.

ASM Handbook. 2004. Introduction to Aluminum-Silicon Casting Alloys. Volume 2. United States of America: ASM International. Hlm. 1-9.

Chu, K.W.M., Daud, A.R. \& Jalar, A. 2008. Pengaruh unsur zirkonium terhadap sifat mekanik aloi tempaan Al-1.2Si0.5Mg-0.25Fe. Sains Malaysiana 37(2): 189-193.

Daud, A.R., Talib, I.A. \& Harun, M. 2001. Effects to magnesium addition on microhardness in Eutectic Al-Si-Mg Alloys. Sains Malaysiana 30: 195-202.

Farkoosh, A.R. \& Pekguleryuz, M. 2015. Enhanced mechanical properties of an Al-Si-Cu-Mg alloy at $300^{\circ} \mathrm{C}$ : Effects of $\mathrm{Mg}$ and the Q-precipitate phase. Materials Science \& Engineering A 621: 277-286.

Kirkwood, D.H., Suery, M., Kapranos, P., Atkinson, H.V. \& Young, K.P. 2010. Semi-Solid Processing of Alloys. London: Springer Series in Materials Science.

Liu, D., Atkinson, H.V. \& Jones, H. 2005. Thermodynamic prediction of thixoformability in alloys based on the Al$\mathrm{Si}-\mathrm{Cu}$ and Al-Si-Cu-Mg systems. Acta Materialia 53(14): 3807-3819.

Maciel, C.A., Atkinson, H.V., Kapranos, P. \& Argent, B.B. 2003. Thermodynamic prediction of wrought alloy compositions amenable to semi-solid processing. Acta Materialia 51(8): 2319-2330.

Mondolfo, L.F. 1976. Aluminium Alloys: Structure and Properties. 1st ed. London: Butterworth-Heinemann.

Omar, M.Z., Atkinson, H.V. \& Kapranos, P. 2011. Thixotropy in semisolid steel slurries under rapid compression. Metallurgical and Materials Transactions A 42(9): 28072819.

Othman, K., Ghani, J.A., Haron, C.H.C., Juri, A. \& Kassim, M.S. 2018. Kajian mikrostruktur aloi aluminium A390 
selepas pemesinan kisar. Jurnal Kejuruteraan 30(2): 257264.

Sadeghi, I., Wells, M.A. \& Esmaeili, S. 2017. Modeling homogenization behaviour of Al-Si-Cu-Mg aluminium alloy. Materials \& Design 128: 241-249. https://doi. org/10.1016/j.matdes.2017.05.006.

Salleh, E.M., Samsu, Z., Othman, N.K. \& Jalar, A. 2018. Kesan suhu celupan ke atas mikrostruktur dan kekerasan salutan aluminium pada keluli karbon. Sains Malaysiana 47(6): 1251-1257.

Salleh, M.S., Omar, M.Z., Syarif, J., Alhawari, K.S. \& Mohammed, M.N. 2014. Microstructure and mechanical properties of thixoformed A319 aluminium alloy. Materials \& Design 64: 142-152.

Shamsudin, R., Daud, A.R. \& Hamid, M.A.A. 2007. Nitridation of Al-Mg-Si alloys through dynamic heating. Sains Malaysiana 36(2): 195-200.

Sjölander, E. \& Seifeddine, S. 2010. The heat treatment of Al$\mathrm{Si}-\mathrm{Cu}-\mathrm{Mg}$ casting alloys. Journal of Materials Processing Technology 210(10): 1249-1259.
Zoqui, E.J., Benati, D.M., Proni, C.T.W. \& Torres, L.V. 2016. Thermodynamic evaluation of the thixoformability of AlSi alloys. Calphad 52: 98-109.

Zuo, L., Ye, B., Feng, J., Kong, X., Jiang, H. \& Ding, W. 2017. Effect of $\mathrm{Q}-\mathrm{Al}_{5} \mathrm{Cu}_{2} \mathrm{Mg}_{8} \mathrm{Si}_{6}$ phase on mechanical properties of $\mathrm{Al}-\mathrm{Si}-\mathrm{Cu}-\mathrm{Mg}$ alloy at elevated temperature. Materials Science and Engineering A 693: 26-32.

Centre for Materials Engineering and Smart Manufacturing (MERCU)

Faculty of Engineering and Built Environment

Universiti Kebangsaan Malaysia

43600 UKM Bangi, Selangor Darul Ehsan

Malaysia

*Pengarang untuk surat-menyurat; email: anifarif@gmail.com

Diserahkan: 11 Mei 2019

Diterima: 12 Oktober 2019 